\title{
Limits of a rapid identification of common Mediterranean sandflies using polymerase chain reaction-restriction fragment length polymorphism
}

\author{
Azzedine Bounamous ${ }^{1,2}$, Véronique Lehrter ${ }^{1}$, Leila Hadj-Henni', \\ Jean-Claude Delecolle ${ }^{3}$, Jérôme Depaquit ${ }^{1 /+}$

\begin{abstract}
'Transmission Vectorielle et Épidémiosurveillance de Maladies Parasitaires EA 4688-USC, Agence Nationale de la Sécurité Sanitaire de I'Alimentation, de l'Enviromment et du Travail, Faculté de Pharmacie, Université de Reims Champagne-Ardenne, Reims, France ${ }^{2}$ Laboratoire des Sciences Naturelles et Matériaux, Institut des Sciences et de la Technologie, Centre Universitaire de Mila, Mila, Algeria ${ }^{3}$ Université de Strasbourg, Strasbourg, France
\end{abstract}

A total of 131 phlebotomine Algerian sandflies have been processed in the present study. They belong to the species Phlebotomus bergeroti, Phlebotomus alexandri, Phlebotomus sergenti, Phlebotomus chabaudi, Phlebotomus riouxi, Phlebotomus perniciosus, Phlebotomus longicuspis, Phlebotomus perfiliewi, Phlebotomus ariasi, Phlebotomus chadlii, Sergentomyia fallax, Sergentomyia minuta, Sergentomyia antennata, Sergentomyia schwetzi, Sergentomyia clydei, Sergentomyia christophersi and Grassomyia dreyfussi. They have been characterised by sequencing of a part of the cytochrome $b$ (cyt b), $t$ RNA serine and NADH1 on the one hand and of the cytochrome C oxidase I of the mitochondrial DNA (mtDNA) on the other hand. Our study highlights two sympatric populations within P. sergenti in the area of its type-locality and new haplotypes of $\mathrm{P}$. perniciosus and $\mathrm{P}$. longicuspis without recording the specimens called lcx previously found in North Africa. We tried to use a polymerase chain reaction-restriction fragment length polymorphism method based on a combined double digestion of each marker. These method is not interesting to identify sandflies all over the Mediterranean Basin.

Key words: Algeria - mtDNA - PCR-RFLP - Phlebotomus sergenti

Algeria is a country where four leishmaniases are endemic. The leishmaniasis due to Leishmania infantum is transmitted by phlebotomine sandflies belonging to the subgenus Larroussius: Phlebotomus perniciosus, Phlebotomus perfiliewi [proven vectors according to Killick-Kendrick (1990)] and possibly Phlebotomus longicuspis (suspected vector) (Izri et al. 1990, Izri \& Belazzoug 1993, Harrat et al. 1996, Berdjane-Brouk et al. 2012). Leishmania major is transmitted by the proven vector Phlebotomus papatasi (Izri et al. 1992). Leishmania tropica and Leishmania killicki are transmitted by the proven vectors Phlebotomus sergenti (Guilvard et al. 1991, Boubidi et al. 2011, Jaouadi et al. 2012).

The phlebotomine sandfly fauna of Algeria has been studied in the past (Parrot 1917, 1935, 1942, Rioux et al. 1970a, b, Dedet et al. 1973, 1984, Dedet \& Addadi 1977, Belazzoug \& Mahzoul 1980, 1986, Belazzoug et al. 1986, Berchi et al. 1986, Belazzoug 1991, Russo et al. 1991). Recently, two molecular studies characterised two closely related species (Phlebotomus chabaudi and Phlebotomus riouxi) having undistinguishable or very difficultly distinguishable females from North Africa (Bounamous et al. 2008, Boudabous et al. 2009) and a new species for the country (and for Africa) has been recorded: Phlebotomus mascittii Grassi (Berdjane-Brouk et al. 2011).

doi: $10.1590 / 0074-0276130584$

+ Corresponding author: jerome.depaquit@univ-reims.fr

Received 16 December 2013

Accepted 17 March 2014
In a recent paper, Latrofa et al. (2012) suggested to use mitochondrial DNA (mtDNA) cytochrome b (cyt b) polymerase chain reaction-restriction fragment length polymorphism (PCR-RFLP) as a rapid molecular identification of the common phlebotomine sandflies in the Mediterranean Region. The goal of this paper is to check the proposed method on a sampling of 17 Algerian species (131 specimens) belonging to three genera: Phlebotomus, Sergentomyia and Grassomyia. We coupled $c y t b$ and cytochrome $\mathrm{C}$ oxidase I $(C O I)$ of the mtDNA. The first marker is considered as the "gold standard" for phlebotomine sandflies systematic. The second one serves as a DNA barcode for the identification of animal species (Hebert et al. 2003). However, it was used in a few studies carried out on phlebotomine sandflies to study taxa from the Americas (Arrivillaga et al. 2002, Azpurua et al. 2010), from North Africa (Boudabous et al. 2009) and in India (Kumar et al. 2012).

\section{MATERIALS AND METHODS}

Sandflies collection - Sandflies were collected from different provinces of Algeria coupling three methods in order to increase the diversity (Rioux et al. 2013): sticky traps, CDC and ultraviolet miniature light traps and aspirators (Fig. 1). They were stored in $96 \%$ ethanol. One hundred thirty-one males and females selected for this study are indicated in the Supplementary data.

Sandflies mounting and identification - The head and genitalia of individual male sandflies were cut off within a drop of ethanol, cleared in boiling Marc-André solution and mounted between slide and cover slide for spe- 


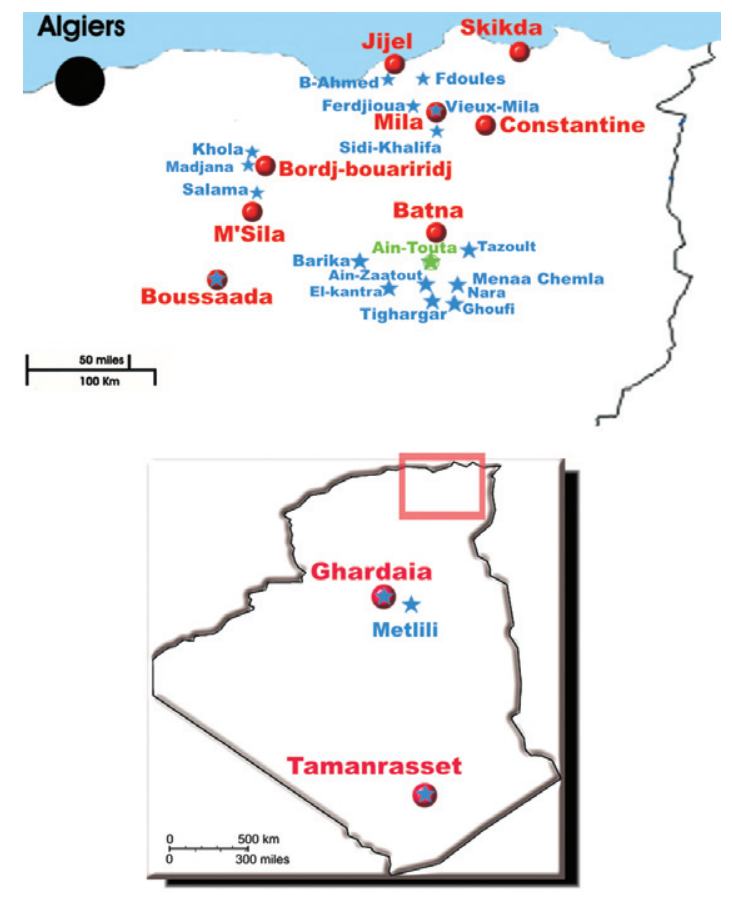

Fig. 1: sampling realised for this study in different areas of Algeria. Aïn-Touta is the type locality of Phlebotomus sergenti. Circles: main cities; stars: locations where sandflies have been caught.

cies identification. The body related to the specimen was stored dried in a vial at $-20^{\circ} \mathrm{C}$ before DNA extraction.

The specimens have been identified by observation of the head and genitalia under a BX50 microscope. The identification keys and characters used for the identification of specimens are those of Abonnenc (1972), Dedet et al. (1984), Depaquit et al. (1998a), Pesson et al. (2004) and Bounamous et al. (2008). Measures and photos have been performed using the Perfect Image software (Aries Company, Chatillon, France) and a video camera connected to the microscope.

DNA extraction - Genomic DNA was extracted from the thorax, wings, legs and abdomen of individual sandflies using the QIAmp DNA Mini Kit (Qiagen, Germany) following the manufacturer's instructions, modified by crushing the sandfly tissues with a piston pellet (Treff, Switzerland) and using an elution volume of 200 $\mu \mathrm{L}$, as detailed in Depaquit et al. (2004).

PCR amplification and sequencing - All the mtDNA amplifications were performed in a $50 \mu \mathrm{L}$ volume using $5 \mu \mathrm{L}$ of extracted DNA solution and 50 pmol of each of the primers. The PCR mix contained (final concentrations) $10 \mathrm{mM}$ Tris $\mathrm{HCl}(\mathrm{pH} 8.3), 1.5 \mathrm{mM} \mathrm{MgCl}_{2}, 50$ $\mathrm{mM} \mathrm{KCl}, 0.01 \%$ Triton X 100, $200 \mu \mathrm{M}$ deoxynucleotide triphosphate each base and 1.25 units of 5 prime Taq polymerase (Eppendorf, Germany).

The cycle profiles were marker dependent. Each PCR begins by an initial denaturation step at $94^{\circ} \mathrm{C}$ for $3 \mathrm{~min}$ and finishes by a final extension at $68^{\circ} \mathrm{C}$ for $1 \mathrm{~min}$. $\mathrm{Am}$ plification of a fragment of $c y t b$ gene has been done by using the primers N1N-PDR and C3B-PDR, following the method previously published by Esseghir et al. (1997): five cycles (denaturation at $94^{\circ} \mathrm{C}$ for $30 \mathrm{~s}$, annealing at $40^{\circ} \mathrm{C}$ for $60 \mathrm{~s}$ and extension at $68^{\circ} \mathrm{C}$ for $60 \mathrm{~s}$ ) followed by 35 cycles (denaturation at $94^{\circ} \mathrm{C}$ for $60 \mathrm{~s}$, annealing at $44^{\circ} \mathrm{C}$ for $60 \mathrm{~s}$ and extension at $68^{\circ} \mathrm{C}$ for $60 \mathrm{~s}$ ). Their $\mathrm{COI}$ domain was amplified using the primers used by Hajibabaei et al. (2006): LepF and LepR, under the following thermal profile (Costa et al. 2007): five cycles (denaturation at $94^{\circ} \mathrm{C}$ for $30 \mathrm{~s}$, annealing at $45^{\circ} \mathrm{C}$ for $90 \mathrm{~s}$ and extension at $68^{\circ} \mathrm{C}$ for $60 \mathrm{~s}$ ), then 35 cycles (denaturation at $94^{\circ} \mathrm{C}$ for $30 \mathrm{~s}$, annealing at $51^{\circ} \mathrm{C}$ for $90 \mathrm{~s}$ and extension at $68^{\circ} \mathrm{C}$ for $60 \mathrm{~s}$ ).

Amplicons were analysed by electrophoresis in 1.5\% agarose gel containing ethidium bromide. Direct sequencing in both directions was performed by Sanger's method using the primers used for DNA amplification. Reagents for PCR cleanup were Agencourt ${ }^{\circledR}$ AMPure XP-PCR Purification and those for sequencing reaction were Big Dye Sequencing Buffer (Applied Biosystems Foster City, California, USA); Agencourt ${ }^{\circledR}$ CleanSEQ kit: CleanSeq $^{\circledR}$ beads. The instruments used for the sequencing were Biomek NXp BiomekFXP (Bekman Coulter); Sequencer 3730 XLT (Applied Biosystems). The correction of sequences was done using Pregap and Gap softwares included in the Staden Package (Bonfield \& Staden 1996).

Molecular analyses - They are based on the two datasets of sequences. Analyses were performed using haplotypes obtained from this study and sequences of $P$. chabaudi and P. riouxi available in GenBank (Supplementary data). Sequence alignment was performed using the CLUSTALW routine included in the MEGA v.4 software (Tamura et al. 2007) and checked by eye. The objective of this study is to provide a database for sandflies identification, not to do any phylogenetical analysis. Consequently, a neighbour-joining (NJ) analysis was performed using MEGA 4 software, with the Kimura-2 parameters model and using uniform rates among sites. Gaps were treated as missing data.

$R F L P$ - The diagnostic endonuclease restriction sites on $c y t b$ and $C O I$ mtDNA sequences were predicted for each specimen using CLC workbench 5.2 software (clc-genomics-workbench.com-about.com). A panel of restriction enzymes was tested including AseI enzyme proposed by Latrofa et al. (2012) for $c y t b$ digestion. Because one restriction enzyme cannot provide an original digestion pattern per species, we selected double digestion for both molecular markers.

PCR-RFLP assays were performed in a $50-\mu \mathrm{L}$ total volume reaction mix, containing $15 \mu \mathrm{L}$ of PCR product (from PCR vials), $0.1 \mu \mathrm{L}$ of AseI, $0.4 \mu \mathrm{L}$ of $M n l \mathrm{I}$ for cytb and $0.05 \mu \mathrm{L}$ of $M s p \mathrm{I}, 0.05 \mu \mathrm{L}$ of TaqI for COI, $5 \mu \mathrm{L}$ of NEB buffer 3 for $c y t b$ and $5 \mu \mathrm{L}$ of NEB buffer 4 for COI containing bovine serum albumin (New England Biolabs, France).

For $c y t b$ PCR-RFLP, we selected a double digestion coupling AseI with $M n l$ I. PCR products were digested during $2 \mathrm{~h}$ at $37^{\circ} \mathrm{C}$.

For COI PCR-RFLP, we selected a double digestion coupling MspI with TaqI. According to their different temperature of activity $\left(37^{\circ} \mathrm{C}\right.$ and $65^{\circ} \mathrm{C}$, respectively), PCR products were digested during $1 \mathrm{~h}$ at $37^{\circ} \mathrm{C}$ then $1 \mathrm{~h}$ at $65^{\circ} \mathrm{C}$. 
The digested samples were separated by electrophoresis in a 3\% agarose gel to produce DNA fragments and sized by comparison with markers $50 \mathrm{bp}$ ladder, $100 \mathrm{bp}$ ladder and 20 bp ladder (Cliniscience, France).

According to the sequencing of all the specimens processed in the present study, we did not use any positive control, but we checked that each restriction enzyme had functioned properly in each reaction by comparison to the predicted digestion.

\section{RESULTS}

PCR amplification was successful for all the specimens processed. The GenBank accessions for COI and $c y t b$ are indicated in the Supplementary data. The length of the analysed markers is of $680 \mathrm{bp}$ for COI. It varies from $510-525 \mathrm{bp}$ for $c y t b$. Each gene from each haplotype had an open reading frame (ORF). The sequences labelled $C O I$ include exclusively this marker. The sequences labelled "cytB" included in fact an ORF of cytB (positions 1-321), the t RNA serine (positions 321-378), then the ORF for NADH subunit 1 (from 379 to the last position). These ORFs are translated in proteins, explaining the low probability they could be pseudogenes (Rogers \& Griffiths-Jones 2012).

Global trees based on $c y t b$ and $C O I$ sequences are presented in Figs 2, 3, respectively. According to Depaquit et al. (1998b), Phlebotomus bergeroti has been selected to root the tree. All the species morphologically recognised are well individualised. We note that $P$. sergenti included two populations without any morphological difference. The identification of $P$. perniciosus and $P$. longicuspis is not doubtful. We did not record any atypical specimen.

The double digestion of each PCR product confirms the expected fragments for all haplotypes (Tables I, II). The resolution of DNA fragment size by the gel fractionation method used is about $10 \mathrm{bp}$. The double digestion of $C O I$ by restriction enzymes TaqI and $M s p$ I is very efficient, but cannot unequivocally distinguish Phlebotomus ariasi and Sergentomyia schwetzi.

The double digestion of $c y t b$ by restriction enzymes AseI and MnlI provide restriction profiles indicated in Table II. On the one hand, it cannot individualise one population of $P$. sergenti, $P$. ariasi and $P$. riouxi. On the other hand, it cannot distinguish $P$. longicuspis and $P$. perfiliewi.

No partial digests were recognised in the analysis.

\section{DISCUSSION}

The specimens identified by morphology as belonging to a species are branched together regarding independently $c y t b$ or $C O I$ sequences (Figs 2,3 ).

$C y t b$ sequences provide a NJ tree in agreement with the traditional morphological taxonomy of the phlebotomine sandflies (Fig. 2). Sergentomyia are grouped together including Grassomyia dreyfussi. Concerning Larroussius, all of them are grouped together and two branches are individualised: one including $P$. ariasi and Phlebotomus chadlii and another containing P. perniciosus, $P$. longicuspis (including 2 lineages) and P. perfiliewi. These data are in accordance with those obtained by Esseghir et al. (2000) on cyt $b$ and Di Muccio et al.
(2000) on rDNA internal transcribed spacer 2. Concerning the subgenus Paraphlebotomus, the species P. sergenti, $P$. chabaudi and $P$. riouxi are grouped together. The first one shows two lineages in its type-locality. Moreover, Phlebotomus alexandri is not included in this branch, as previously observed (Depaquit et al. 2000, Krüger et al. 2011).

The NJ tree based on COI sequences (Fig. 3) has a surprising topology: the species belonging to the subgenera Sergentomyia, Larroussius and Paraphlebotomus are not grouped together. Despite this curious branching, some results are congruent with cyt $b$ : (i) the position of $P$. alexandri, (ii) the existence of two molecular lineages within $P$. sergenti topotypes, (iii) the individualisation of $P$. chabaudi and $P$. riouxi, (iv) the existence of two lineages within P. longicuspis and (v) a high variability within Sergentomyia minuta and Sergentomyia antennata.

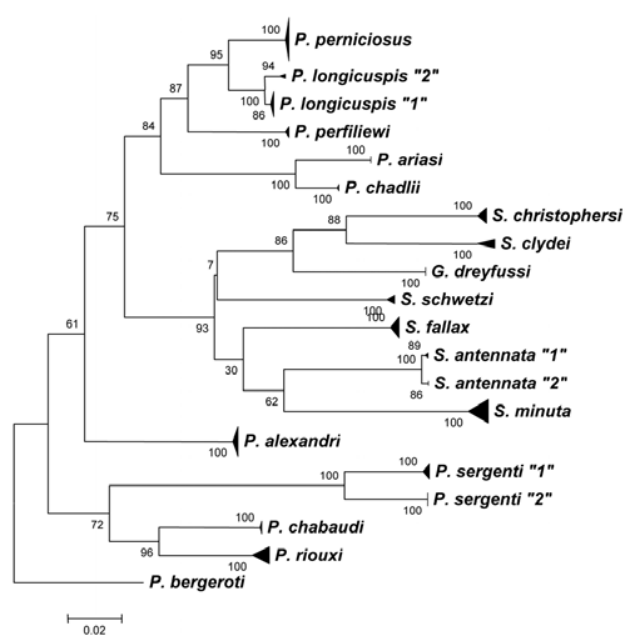

Fig. 2: neighbour-joining tree based on mitochondrial DNA cytochrome b sequences rooted on Phlebotomus bergeroti. Bootstrap values after 1,000 replicates are indicated on the branches.

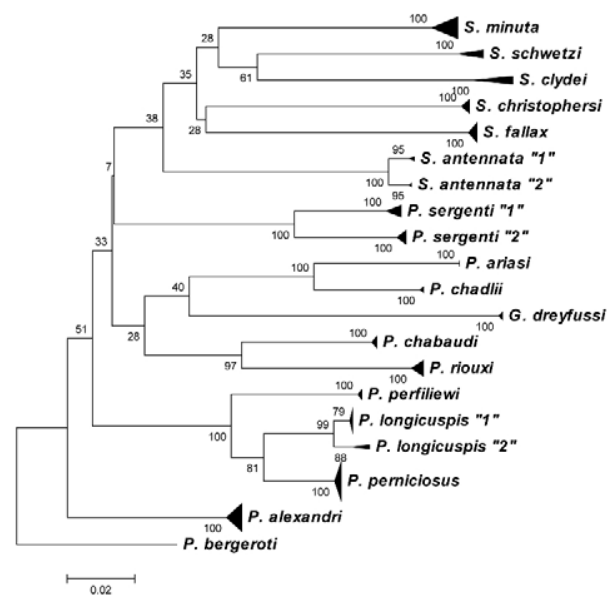

Fig. 3: neighbour-joining tree based on mitochondrial DNA cytochrome C oxidase I sequences rooted on Phlebotomus bergeroti. Bootstrap values after 1,000 replicates are indicated on the branches. 
Many lineages have been identified in P. sergenti in the literature from populations from different parts of the species distribution area and no study emphasise a link between the molecular variability and the morphology (Depaquit et al. 2002, Yahia et al. 2004, Moin-Vaziri et al. 2007, Barón et al. 2008, Dvorak et al. 2011). The two mitochondrial lineages ( $c y t b$ as well as $C O I$ ) within Algerian specimens of $P$. sergenti coming from different localities, all located just around the type locality area (Fig. 1) called Ain Touta, formerly Mac Mahon (Parrot 1917). This locality has not been precisely designated by Parrot (1917). The specimens processed in the present study can be considered as being topotypes, clearly labelled and stored in the collection of the laboratory of Parasitology of the Faculty of Pharmacy of Reims. These two populations are strongly separated and are characterised by many variable nucleotidic positions: about 30 for $c y t b$ and 40 for $C O I$ (Fig. 4). The mean pairwise distance between the two populations of $P$. sergenti $(>5 \%)$ is comparable to the pairwise distances individualising $P$. perniciosus from $P$. longicuspis or $P$. perfiliewi in the present study and question about the status of these populations.

The haplotypes obtained for $P$. perniciosus and $P$. longicuspis have been compared with those of $c y t b$ available in the literature (Esseghir et al. 1997, Pesson et al. 2004, Perrotey et al. 2005) (Fig. 5). The main $P$. perniciosus Algerian haplotype is the same than the main Mediterranean haplotype (= pern01), but three new haplotypes are recorded from Algeria for this species.
Concerning P. longicuspis, the most common haplotype is the lcus01. However, we record four new haplotypes including a couple (LC2 and LC637) strongly individualised from the other ones. The COI sequences also individualise the latter specimens from all other $P$. longicuspis (Fig. 3).

Recently, the single digestion based on $c y t b$ sequences by Latrofa et al. (2012) as a rapid molecular identification method for the common phlebotomine sandflies in the Mediterranean Region does not apply in Algeria. In fact, these authors focused on five species only, commonly caught in Italy: P. papatasi, $P$. perniciosus, $P$. perfiliewi, Phlebotomus neglectus and $S$. minuta. We tried this method on the Algerian sandflies, including P. papatasi. The method is not able to distinguish all the species and the combined double digestion of two different markers is needed for the specific identification. Due to the conservation of some parts of DNA sequences, the simple digestion of PCR products cannot separate some species belonging to different genera (like $P$. ariasi and $S$. schwetzi) or subgenera (like $P$. sergenti and $P$. ariasi). Consequently, this method is not enough discriminant to be used in routine all over the Mediterranean Basin. In fact, it is easier to firstly identify the species easy to recognise by a microscopical examination and secondly, to apply efficient PCR-RFLP methods to identify the species for which morphological identification is difficult, like the females of the Perniciosus complex, those of $P$. chabaudi and $P$. riouxi and for some Sergentomyia males.

\section{TABLE I}

Species and populations examined in the present study - number and positions of cuts predicted for cytochrome C oxidase I mitochondrial DNA restriction fragment length polymorphism

\begin{tabular}{|c|c|c|c|}
\hline \multirow[b]{2}{*}{ Species } & \multicolumn{2}{|c|}{$\begin{array}{l}\text { TaqI and } M s p 1 \\
\quad(\text { expected) }\end{array}$} & \multirow[b]{2}{*}{ Cut sites } \\
\hline & $\begin{array}{l}\text { Cut } \\
\text { (n) }\end{array}$ & $\begin{array}{l}\text { Fragments } \\
\text { (n) }\end{array}$ & \\
\hline Phlebotomus bergeroti & 4 & 5 & $85,91,101,176,254$ \\
\hline Phlebotomus alexandri & 5 & 6 & $22,84,85,91,156,267$ \\
\hline Phlebotomus longicuspis & 4 & 5 & $22,73,91,113,408$ \\
\hline Phlebotomus perniciosus & 3 & 4 & $22,91,184,408$ \\
\hline Phlebotomus chabaudi & 5 & 6 & $30,85,89,91,158,256$ \\
\hline Phlebotomus sergenti (group 1) & 3 & 4 & $25,62,111,507$ \\
\hline Phlebotomus sergenti (group 2) & 3 & 4 & $22,85,91,507$ \\
\hline Phlebotomus chadlii & 6 & 7 & $14,22,85,91,101,174,224$ \\
\hline Phlebotomus riouxi & 6 & 7 & $21,30,85,91,141,157,186$ \\
\hline Phlebotomus ariasi & 2 & 3 & $85,91,527$ \\
\hline Phlebotomus perfiliewi & 2 & 3 & $11,184,408$ \\
\hline Sergentomyia fallax & 2 & 3 & $85,265,353$ \\
\hline Sergentomyia schwetzi & 2 & 3 & $85,91,527$ \\
\hline Sergentomyia clydei & 4 & 5 & $82,91,174,176,184$ \\
\hline Sergentomyia minuta & 3 & 4 & $88,90,176,350$ \\
\hline Sergentomyia christophersi & 5 & 6 & $32,81,85,91,101,319$ \\
\hline Sergentomyia dreyfussi & 3 & 4 & $70,91,184,360$ \\
\hline Sergentomyia antennata & 3 & 4 & $82,110,157,356$ \\
\hline
\end{tabular}




\section{TABLE II}

Species and populations examined in the present study - number and positions of cuts predicted for cytochrome $\mathrm{b}$ mitochondrial DNA restriction fragment length polymorphism

\begin{tabular}{lccc}
\hline & AseI and MnlI (expected) & \\
\cline { 2 - 4 } & Cut & Fragments & Cut sites \\
Species & (n) & (n) & $14,20,74,434$ \\
\hline Phlebotomus bergeroti & 3 & 4 & $14,20,62,92,108,248$ \\
Phlebotomus alexandri & 5 & 6 & $14,20,62,92,103,263$ \\
Phlebotomus longicuspis & 5 & 6 & $14,20,62,103,353$ \\
Phlebotomus perniciosus & 4 & 5 & $14,20,62,198,248$ \\
Phlebotomus chabaudi & 4 & 5 & $14,20,96,208,209$ \\
Phlebotomus sergenti (group 1) & 4 & 5 & $14,20,62,449$ \\
Phlebotomus sergenti (group 2) & 3 & 4 & $20,62,107,356$ \\
Phlebotomus chadlii & 3 & 4 & $14,20,62,445$ \\
Phlebotomus riouxi & 3 & 4 & $14,20,62,453$ \\
Phlebotomus ariasi & 3 & 4 & $14,20,62,92,103,263$ \\
Phlebotomus perfiliewi & 5 & 6 & $20,62,103,353$ \\
Sergentomyia fallax & 3 & 4 & $20,52,52,62,356$ \\
Sergentomyia schwetzi & 4 & 5 & $10,20,62,103,134,212$ \\
Sergentomyia clydei & 5 & 6 & $14,19,20,42,74,93,296$ \\
Sergentomyia minuta & 6 & 7 & $20,34,46,58,62,134,184$ \\
Sergentomyia christophersi & 6 & 7 & $14,15,20,28,62,103,134,171$ \\
Sergentomyia dreyfussi & 7 & 8 & 20,515 \\
Sergentomyia antennata & 1 & 2 &
\end{tabular}

CytochromeB:

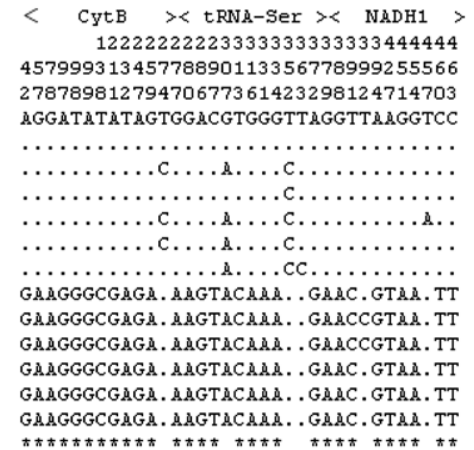

COI:

1111122222222233333333333444444555555555666 567889902889013334579013344778991123480133455581225 359894735476272587088401739695145873840523714701282 SE304-COI ACCATTTAATTTTGTCACCTATAGAATTACCTATAACTAACTTCGTTCG

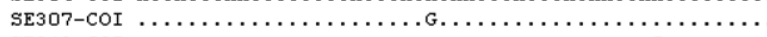

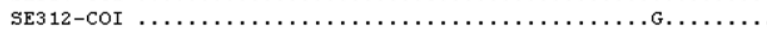

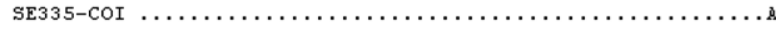

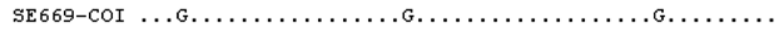

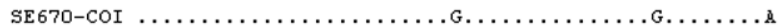

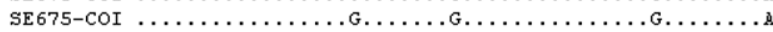
SE305-COI GTT.CCC......CCACTCTTC.C.\&.GCCCCTTCGCG.TCGGTC.TACCTT SE394-COI GTT.CCCGG.C.CCACTCTTC.G. AGGCCCCTTCGCG.TCGGTC.TACCTT SE539-COI GTT.CCCGG.C.CCACTCTTC.G. AGGCCCCTTCGCG. TCGGTC.TACCTT SE540-COI GTT.CCCG..C.CCACTCTTC.C.\&.GCCCCTTCGCG.TCGGTC.TACCTT SE627-COI GTT.CC.G..C.CCACTCTTC.C.A.GCCCCTTC.CG.TCGGTC.TACCTT SE621-COI GTT.CCCG. ACACCACTCTTC.C.A.GCCCCTTCGCGGTCGGTCCT\&CCTT

Fig. 4: variable positions observed within Phlebotomus sergenti for cytochrome $\mathrm{b}$ and cytochrome $\mathrm{C}$ oxidase $\mathrm{I}(\mathrm{COI}) \mathrm{mi}-$ tochondrial DNA. Stars indicate the sites characterising the two populations.

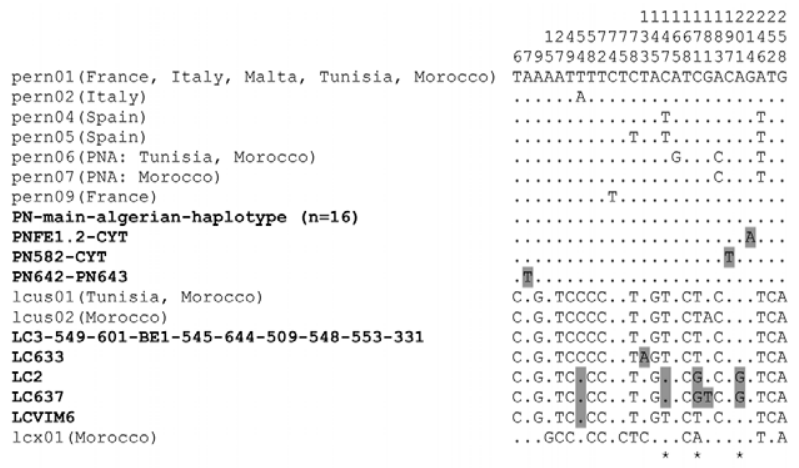

Fig. 5: alignment of cytochrome b haplotypes concerning Phlebotomus perniciosus and Phlebotomus longicuspis and showing exclusively the variable sites reported by Esseghir et al. (1997), Pesson et al (2004) and Perrotey et al. (2005). The Algerian haplotypes are written in bold. The variations observed in Algerian specimens are underlined. The stars indicate the sites individualising the haplotypes LC2 and LC637.

\section{ACKNOWLEDGEMENTS}

To Kaouther Jaouadi, Mohammad Akhoundi and Mireille Cousinat, for their help, and to Sylvette Gobert, for proofreading this paper.

\section{REFERENCES}

Abonnenc E 1972. Les phlébotomes de la région éthiopienne (Diptera, Psychodidae). Cah Orstom (Sci Hum) 55: 1-239. 
Arrivillaga JC, Norris DE, Feliciangeli MD, Lanzaro GC 2002. Phylogeography of the neotropical sand fly Lutzomyia longipalpis inferred from mitochondrial DNA sequences. Infect Genet Evol 2: 83-95.

Azpurua J, de La Cruz D, Valderama A, Windsor D 2010. Lutzomyia sand fly diversity and rates of infection by Wolbachia and an exotic Leishmania species on Barro Colorado Island, Panama. PLoS Negl Trop Dis 4: e627.

Barón S, Martín-Sánchez J, Gállego M, Morales-Yuste M, Boussaa S, Morillas-Márquez F 2008. Intraspecific variability (rDNA ITS and mtDNA cyt b) of Phlebotomus sergenti in Spain and Morocco. Acta Trop 107: 259-267.

Belazzoug S 1991. The sand flies of Algeria. Parassitologia 33 (Suppl.): 85-87.

Belazzoug S, Mahzoul D 1980. Note sur les phlébotomes (Diptera, Psychodidae) du Tassili N'ajjer. Arch Inst Pasteur Alger 54: 103-106.

Belazzoug S, Mahzoul D 1986. Note sur les phlébotomes (Diptera, Psychodidae) du Hoggar. Arch Inst Pasteur Alger 55: 113-116.

Belazzoug S, Mahzoul D, Rioux JA 1986. Les phlébotomes (Diptera, Psychodidae) de M'Sila et Bousaada. Arch Inst Pasteur Alger 55: 117-124

Berchi S, Rioux JA, Belmonte A, Russo J 1986. Un phlébotome nouveau pour l'Algérie: Phlebotomus (Paraphlebotomus) kazeruni. Ann Parasitol Hum Comp 61: 507-508.

Berdjane-Brouk Z, Charrel RN, Bitam I, Hamrioui B, Izri A 2011. Record of Phlebotomus (Transphlebotomus) mascittii Grassi, 1908 and Phlebotomus (Larroussius) chadlii Rioux, Juminer \& Gibily, 1966 female in Algeria. Parasite 18: 337-339.

Berdjane-Brouk Z, Charrel RN, Hamrioui B, Izri A 2012. First detection of Leishmania infantum DNA in Phlebotomus longicuspis Nitzulescu, 1930 from visceral leishmaniasis endemic focus in Algeria. Parasitol Res 111: 419-422.

Bonfield JK, Staden R 1996. Experiment files and their application during large-scale sequencing projects. DNA Seq 6: 109-117.

Boubidi S, Benallal K, Boudrissa A, Bouiba L, Bouchareb B, Garni R, Bouratbine A, Ravel C, Dvorak V, Votypka J, Volf P, Harrat Z 2011. Phlebotomus sergenti (Parrot, 1917) identified as Leishmania killicki host in Ghardaïa, south Algeria. Microbes Infect 13: 691-696.

Boudabous R, Bounamous A, Jouet D, Depaquit J, Augot D, Ferté H, Berchi S, Veuille M, Babba H 2009. Mitochondrial DNA differentiation between two closely related species Phlebotomus chabaudi Croset, Abonnenc \& Rioux, 1970 and P. riouxi Depaquit, Killick-Kendrick \& Léger, 1998 based on direct sequencing and PCR-RFLP. Ann Entomol Soc Am 102: 347-353.

Bounamous A, Boudabous R, Jouet D, Augot D, Ferté H, Babba H, Berchi S, Depaquit J 2008. Caractérisation moléculaire et morphologique de deux espèces affines de Paraphlebotomus: Phlebotomus chabaudi Croset, Abonnenc and Rioux, 1970 et P. riouxi Depaquit, Killick-Kendrick, Léger, 1998 (Diptera, Psychodidae). Parasite 15: 565-571.

Costa FO, Dewaard JR, Boutillier J, Ratnasingham S, Dooh RT, Hajibabaei M, Hebert PDN 2007. Biological identifications through DNA barcodes: the case of the Crustacea. Can J Fish Aquat Sci 64: 272-295.

Dedet JP, Addadi K 1977. Epidémiologie des leishmanioses en Algérie. 4. Les phlébotomes (Diptera, Psychodidae) des Aurès. Arch Inst Pasteur Alger 52: 85-94.

Dedet JP, Addadi K, Tabet-Derraz O 1973. Epidémiologie des leishmanioses en Algérie 1. captures de phlébotomes (Diptera, Psychodidae) à Biskra. Présence de Sergentomyia christophersi (Sinton, 1927) en Algérie. Arch Inst Pasteur Alger 51: 183-194.
Dedet JP, Belazzoug S, Addadi K 1984. Les phlébotomes (Diptera, Psychodidae) d'Algérie. Cah Orstom (Sci Hum) 22: 99-127.

Depaquit J, Ferté H, Léger N, Killick-Kendrick R, Rioux JA, KillickKendrick M, Hanafi HA, Gobert S 2000. Molecular systematics of the phlebotomine sand flies of the subgenus Paraphlebotomus (Diptera, Psychodidae, Phlebotomus) based on ITS2 rDNA sequences. Hypotheses of dispersion and speciation. Insect Mol Biol 9: 293-300.

Depaquit J, Ferté H, Léger N, Lefranc F, Alves-Pires C, Hanafi H, Maroli M, Morillas-Marquez F, Rioux JA, Svobodova M, Volf P 2002. ITS2 sequences heterogeneity in Phlebotomus sergenti and Phlebotomus similis (Diptera, Psychodidae): possible consequences in their ability to transmit Leishmania tropica. Int $J$ Parasitol 32: 1123-1131.

Depaquit J, Léger N, Killick-Kendrick R 1998a. Description de Phlebotomus (Paraphlebotomus) riouxi n. sp. d'Afrique du Nord. Parasite 5: 151-158.

Depaquit J, Léger N, Robert V 2004. Description du mâle et redescription de la femelle de Phlebotomus (Anaphlebotomus) berentiensis (Léger \& Rodhain, 1978). Parasite 11: 201-209.

Depaquit J, Perrotey S, Lecointre G, Tillier A, Tillier S, Ferté H, Kaltenbach M, Léger N 1998b. Systématique moléculaire des Phlebotominae: étude pilote. Paraphylie du genre Phlebotomus. $C R$ Acad Sci III 321: 849-855.

Di Muccio T, Marinucci M, Frusteri L, Maroli M, Pesson B, Gramiccia M 2000. Phylogenetic analysis of Phlebotomus species belonging to the subgenus Larroussius (Diptera, Psychodidae) by ITS2 rDNA sequences. Insect Biochem Mol Biol 30: 387-393.

Dvorak V, Votypka J, Aytekin AM, Alten B, Volf P 2011. Intraspecific variability of natural populations of Phlebotomus sergenti, the main vector of Leishmania tropica. J Vector Ecol 36 (Suppl. 1): S49-S57.

Esseghir S, Ready PD, Ben-Ismail R 2000. Speciation of Phlebotomus sandflies of the subgenus Larroussius coincided with the late Miocene-Pliocene aridification of the Mediterranean subregion. Biol J Linn Soc Lond 70: 189-219.

Esseghir S, Ready PD, Killick-Kendrick R, Ben-Ismail R 1997. Mitochondrial haplotypes and geographical variance of Phlebotomus vectors of Leishmania major. Insect Mol Biol 6: 211-255.

Guilvard E, Rioux JA, Gallego M, Pratlong F, Mahjour J, MartinezOrtega E, Dereure J, Saddiki A, Martini A 1991. Leishmania tropica au Maroc. III. Rôle vecteur de Phlebotomus sergenti. A propos de 89 isolats. Ann Parasitol Hum Comp 66: 96-99.

Hajibabaei M, Janzen DH, Burns JM, Hallwachs W, Hebert PDN 2006. DNA barcodes distinguish species of tropical Lepidoptera. PNAS 103: 968-971.

Harrat Z, Pratlong F, Belazzoug S, Dereure J, Deniau M, Rioux JA, Belkaid M, Dedet JP 1996. Leishmania infantum and L. major in Algeria. Trans R Soc Trop Med Hyg 90: 625-629.

Hebert PDN, Cywinska A, Ball SL, de Waard JR 2003. Biological identifications through DNA barcodes. Proc R Soc Lond B Biol Sci 270: 313-321.

Izri MA, Belazzoug S 1993. Phlebotomus (Larroussius) perfiliewi naturally infected with dermotropic Leishmania infantum at Tenes, Algeria. Trans R Soc Trop Med Hyg 87: 399.

Izri MA, Belazzoug S, Boudjebla Y, Dereure J, Pratlong S, DelalbreBelmonte A, Rioux JA 1990. Leishmania infantum MON-1 isolé chez Phlebotomus perniciosus en Kabylie (Algérie). Ann Parasitol Hum Comp 65: 151-152.

Izri MA, Belazzoug S, Pratlong F, Rioux JA 1992. Isolement de Leishmania major chez Phlebotomus papatasi à Biskra (Algérie). Fin d'une épopée écoépidémiologique. Ann Parasitol Hum Сотр 67: 31-32. 
Jaouadi K, Depaquit J, Haouas N, Chaara D, Gorcii M, Chargui N, Dedet JP, Pratlong F, Boubabous R, Babba H 2012. Twenty-four new human cases of cutaneous leishmaniasis due to Leishmania killicki in Metlaoui, southwestern Tunisia. Probable role of Phlebotomus sergenti in the transmission. Acta Trop 122: 276-283.

Killick-Kendrick R 1990. Phlebotomine vectors of the leishmaniases: a review. Med Vet Entomol 4: 1-24.

Krüger A, Strüven L, Post RJ, Faulde M 2011. The sand flies (Diptera: Psychodidae, Phlebotominae) in military camps in northern Afghanistan (2007-2009), as identified by morphology and DNA 'barcoding'. Ann Trop Med Parasitol 105: 163-176.

Kumar NP, Srinivasan R, Jambulingam P 2012. DNA barcoding for identification of sand flies (Diptera: Psychodidae) in India. $\mathrm{Mol}$ Ecol Resour 12: 414-420.

Latrofa MS, Annoscia G, Dantas-Torres F, Traversa D, Otranto D 2012. Towards a rapid molecular identification of the common phlebotomine sand flies in the Mediterranean Region. Vet Parasitol 184: 267-270.

Moin-Vaziri V, Depaquit J, Yaghoobi-Ershadi MR, Oshaghi MA, Derakhshandeh-Peykar P, Ferté H, Kaltenbach M, Bargues MD, Léger N, Nadim A 2007. Intraspecific variation within Phlebotomus sergenti Parrot (1917) (Diptera: Psychodidae) based on mtDNA sequences in Islamic Republic of Iran. Acta Trop 102: 29-37.

Parrot L 1917. Sur un nouveau phlébotome algérien Phlebotomus sergenti, sp. nov. Bull Soc Pathol Exot 10: 564-567.

Parrot L 1935. Les espèces algériennes du genre Phlebotomus (Psychodidae). Bull Soc Hist Nat Afr Nord 26: 145-149.

Parrot L 1942. Notes sur les phlébotomes. XXXIX - à propos de deux Prophlebotomus d'Algérie: Phlebotomus minutus var. Signatipennis et Phlebotomus fallax. Arch Inst Pasteur Alger 20: 322-335.
Perrotey S, Mahamdallie SS, Pesson B, Richardson KJ, Gállego M, Ready PD 2005. Postglacial dispersal of Phlebotomus perniciosus into France. Parasite 12: 283-291.

Pesson B, Ready JS, Benabdennbi I, Martín-Sánchez J, Esseghir S, Cadi-Soussi M, Morillas-Marquez F, Ready PD 2004. Sand flies of the Phlebotomus perniciosus complex: mitochondrial introgression and a new sibling species of P. longicuspis in the Moroccan Rif. Med Vet Entomol 18: 25-37.

Rioux JA, Carron S, Dereure J, Périères J, Zeraia L, Franquet E, Babinot M, Gállego M, Prudhomme J 2013. Ecology of leishmaniasis in the South of France. 22. Reliability and representativeness of 12 Phlebotomus ariasi, P. perniciosus and Sergentomyia minuta (Diptera: Psychodidae) sampling stations in Vallespir (eastern French Pyrenees Region). Parasite 20: 34.

Rioux JA, Croset H, Guy Y 1970a. Présence de Phlebotomus (Paraphlebotomus) chabaudi Croset, Abonnenc et Rioux, 1970 en Algérie. Ann Parasitol Hum Comp 45: 875-880.

Rioux JA, Guy Y, Le Corroller Y, Croset H, Addadi K 1970b. Présence en Algérie de Phlebotomus (Larroussius) chadlii Rioux, Juminer et Gibily, 1966. Bull Soc Pathol Exot 63: 101-104.

Rogers HH, Griffiths-Jones S 2012. Mitochondrial pseudogenes in the nuclear genomes of Drosophila. PLoS ONE 7: e32593.

Russo J, Rioux JA, Lambert M, Rispail P, Belmonte A, Berchi S 1991. Chorologie des phlébotomes de l'est algérien (Diptera, Phlebotominae). Ann Parasitol Hum Comp 66: 247-251.

Tamura K, Dudley J, Nei M, Kumar S 2007. MEGA4: Molecular Evolutionary Genetics Analysis (MEGA) software version 4.0. $\mathrm{Mol}$ Biol Evol 24: 1596-1599.

Yahia H, Ready PD, Hamdani A, Testa JM, Guessous-Idrissi N 2004. Regional genetic differentiation of Phlebotomus sergenti in three Moroccan foci of cutaneous leishmaniasis caused by Leishmania tropica. Parasite 11: 189-199. 